\title{
Aneta Kowalczyk
}

Uniwersytet Rzeszowski

\section{OBIEKTYWNE KRYTERIA USTALANIA WYSOKOŚCI WYNAGRODZENIA A UKŁADY ZBIOROWE PRACY}

1. OBIEKTYWIZM KRYTERIÓW USTALANIA WYSOKOŚCI ŚWIADCZEŃ ZE STOSUNKU PRACY W POWSZECHNYCH ŹRÓDŁACH PRAWA

Przejawem specyfiki prawa pracy w zakresie źródeł prawa jest występowanie autonomicznych źródeł prawa, do których zgodnie z art. $9 \mathrm{kp}$ zaliczamy układy zbiorowe pracy, regulaminy, statuty oraz porozumienia zbiorowe oparte na ustawie. Ich cechą wspólną jest to, że nie są one tworzone przez wyspecjalizowane organy państwowe, różni je natomiast charakter prawny i podmioty biorące udział w ich tworzeniu. Są one albo porozumieniami zbiorowymi, jak układy zbiorowe, albo aktami o charakterze jednostronnym, jak regulaminy. Charakter prawny tych źródeł determinują niejako podmioty, które mają wpływ na ich ostateczną treść, są to bowiem albo partnerzy społeczni, albo wyjątkowo sam pracodawca, jeżeli nie zdołał dojść do konsensusu ze związkami zawodowymi lub tego typu przedstawicielstw pracowniczych brak. Podmioty tworzące autonomiczne źródła prawa pracy mają być z kolei gwarantem obiektywizmu kryteriów ustalania wysokości świadczeń ze stosunku pracy, w tym wynagrodzenia za pracę.

Autonomiczne źródła prawa pracy, w szczególności układy zbiorowe pracy, po pierwsze, uzupełniają normy prawa powszechnie obowiązującego, po drugie, będąc wyrazem autonomii woli partnerów społecznych, dają możliwość kształtowania świadczeń ze stosunku pracy na 
poziomie akceptowalnym przez tychże partnerów, po trzecie są wyrazem samorządności partnerów w zakresie tworzenia własnego prawa, co wiąże się z odpowiedzialnością nie tylko za kształt tychże norm, ale i ich przestrzeganie ${ }^{1}$. Nie bez znaczenia jest również fakt, że ze względu na niemożność kształtowania warunków wynagradzania na poziomie niższym aniżeli normy powszechnie obowiązujące, źródła te powinny wpływać na poprawę stopy życiowej pracowników²

Jedną z fundamentalnych zasad zbiorowego prawa pracy jest zasada dialogu społecznego, która dotyczy wielu instytucji prawa pracy. Najpełniej realizuje się ona $\mathrm{w}$ rokowaniach prowadzonych między innymi celem zawarcia układów zbiorowych pracy ${ }^{3}$. Dialog społeczny jest jednym $\mathrm{z}$ instrumentów ochrony interesów pracowników, a przejawów jego instytucjonalizacji można doszukiwać się między innymi w niektórych autonomicznych źródłach zbiorowego prawa pracy, których charakterystycznym sposobem tworzenia są rokowania partnerów społecznych. Do źródeł tych zaliczamy układy zbiorowe pracy, w przeciwieństwie do regulaminów wynagradzania, bowiem mogą być one ustalone również samodzielnie przez pracodawcę. W przypadku natomiast, gdy ustawodawca wprowadza wymóg ustalania ich treści z zakładową organizacją związkową, nie wydaje się, aby obligował pracodawcę do uzgodnienia ich treści ze związkiem zawodowym, skoro nie mają one charakteru porozumień ${ }^{4}$.

1 Por. L. Florek, Ustawa i umowa w prawie pracy, Warszawa 2010, s. 225; J. Wratny, Państwo jako regulator stosunków pracy - tendencje zmian, «PiZS»10/2004, s. 2; H. SzEWCZYк, Układ zbiorowy pracy jako źródło dyferencjacji warunków zatrudnienia, «Monitor Prawa Pracy» 5/2014, s. 229.

2 Por. W. Szubert, Rola układów zbiorowych $w$ dalszym rozwoju prawa pracy, Łódź 1974, s. 19.

3 G. GoźDziewicz, Podstawowe zasady zbiorowego prawa pracy [w:] Zbiorowe prawo pracy w społecznej gospodarce rynkowej, red. G. GoźDzIEwICZ, Toruń 2000, s. 47.

4 W. MASEwiCz, Ustawa o związkach zawodowych. Ustawa o rozwiązywaniu sporów zbiorowych, Warszawa 1998, s. 69; Z. SALwA, Uprawnienia związków zawodowych, Bydgoszcz 1998, s. 77 i n.; A KowAlCzy , Rola związków zawodowych w negocjacjach w sprawach pracowniczych, [w:] Prawo pracy czynnikiem skutecznego kierowania ludźmi, red. A. NowaK, Radom 2013, s. 224-225. 
Źródła zbiorowego prawa pracy wymienione w przytaczanych wyżej przepisach kodeksu pracy mają zatem zróżnicowany charakter prawny, co jest nie bez znaczenia przy ocenie obiektywizmu kryteriów ustalania świadczeń ze stosunku pracy. Bez wątpienia $\mathrm{z}$ większym prawdopodobieństwem uwzględnienia, przynajmniej częściowo, oczekiwań pracowników co do wysokości świadczeń, będziemy mieć do czynienia w przypadku tych spośród autonomicznych źródeł prawa pracy, które mają charakter porozumień. Z drugiej jednak strony, nieuwzględnianie oczekiwań pracowników przy kształtowaniu świadczeń ze stosunku pracy nie przesądza o braku obiektywizmu podmiotów tworzących te kryteria. Może być ono bowiem konsekwencją niewspółmierności żądań do możliwości pracodawcy czy też braku podstaw do wyższych świadczeń ze względu na rodzaj wykonywanej pracy. Pojawia się w związku z tym pytanie, kiedy kryteria ustalania świadczeń ze stosunku pracy, w tym przede wszystkim wysokości wynagrodzenia za pracę, są kryteriami obiektywnymi?

2. AUtONOMICZNE ŹRÓDŁA PRAWA PRACY A KRYTERIA USTALANIA WYSOKOŚCI WYNAGRODZENIA

Kodeks pracy w art. $78 \$ 1$ wprowadza bardzo ogólne kryteria ustalania wysokości wynagrodzenia, cedując $\mathrm{w} \$ 2$ tegoż przepisu obowiązki w tym zakresie na podmioty tworzące autonomiczne źródła prawa pracy, wskazując konieczność określenia wysokości i zasad przyznawania pracownikom stawek wynagrodzenia za pracę. Ustawodawca nie wprowadza katalogu zamkniętego takich kryteriów, a jedynie wskazuje czynniki determinujące wysokość tego świadczenia, czyli rodzaj wykonywanej pracy, kwalifikacje pracownika, a w szczególności, czy odpowiadają one rodzajowi pracy, ilość i jakość świadczonej pracy. Strony autonomicznych źródeł prawa pracy mają zatem sporą dowolność w zakresie kształtowania kryteriów ustalania wysokości wynagrodzenia pracowników. Ustawodawca obliguje je jednak do określenia wysokości i zasad przyznawania pracownikom stawek wynagrodzenia za pracę, przy uwzględnieniu rodzaju pracy i stanowiska. 
W oparciu o analizę wyżej wskazanego przepisu można stwierdzić, że obiektywne kryteria ustalania wysokości wynagrodzenia to te, które zostały ustalone w układzie zbiorowym pracy czy regulaminie wynagradzania oraz odpowiadają rodzajowi wykonywanej pracy i zajmowanemu stanowisku. Ustawodawca zatem środek ciężkości w zakresie ustalania kryteriów wynagradzania pracowników przesuwa na partnerów społecznych. Należy jednak pamiętać, że spora grupa pracowników nie jest objęta autonomicznymi źródłami prawa pracy.

Jak zostało to już wcześniej podkreślone, najistotniejszą rolę w hierarchii autonomicznych źródeł prawa pracy pełnią układy zbiorowe pracy. Układy zbiorowe pracy jako źródło są jednocześnie jednym z podstawowych narzędzi dyferencjacji prawa pracy, jako że dają możliwość różnicowania uprawnień pracowniczych zgodnie z autonomiczną wolą podmiotów tworzących te układy. Pełnią również funkcję promocyjną, która $\mathrm{z}$ kolei jest przejawem działania w celu ujednolicenia uprawnień pracowników zatrudnionych $\mathrm{w}$ różnych gałęziach i u różnych pracodawców ${ }^{5}$.

W związku jednak z tendencją decetralizacji regulowania uprawnień pracowniczych, która powinna wpływać pozytywie na rozwój prawa pracy, układy zbiorowe pracy powinny być przede wszystkim narzędziem dyferencjacyjnym ${ }^{6}$. W takim ujęciu to na partnerach społecznych powinien spoczywać ciężar kształtowania norm prawa pracy, tak jak to ma miejsce w krajach Europy Zachodniej, gdzie rola państwa polega na tworzeniu minimalnych standardów w zakresie warunków zatrudnienia ${ }^{7}$. Z tym optymalnym modelem kształtowania warunków zatrudnienia nie mamy niestety do czynienia $\mathrm{w}$ warunkach polskich. Od wielu już bowiem lat polski system prawa pracy charakteryzuje się

\footnotetext{
5 Por. J. Wratny, Problem funkcji promocyjnej układów zbiorowych pracy $w$ świetle zmian prawa pracy, [w:] Nowe układy zbiorowe. Przełom czy kontynuacja?, red. J. Wratny Warszawa 1997, s. 40.

6 Por. H. Szewczy , Układ zbiorowy pracy..., s. 231; T. Zieliński, Prawo pracy. Zarys systemu. Cz. I Ogólna, Warszawa-Kraków 1986, s. 150.

7 Por. J. WRatny, Źródła prawa pracy w ujęciu prawnoporównawczym, [w:] Źródła i instytucje prawa pracy w ujęciu porównawczym, red. J. WRATnY, Warszawa 1987, s. 7
} i n. 
zbyt małą mobilnością dyferencjacyjną ${ }^{8}$. Zarzut ten dotyczy bez wątpienia układów zbiorowych pracy. Przyczyn takiego stanu rzeczy jest wiele i są one zróżnicowane, ale do dominujących można zaliczyć zbyt małą liczbę zawieranych układów zbiorowych, z których zdecydowana większość są to układy zakładowe. Pozornie fakt dominacji układów zakładowych powinien sprzyjać realizowaniu funkcji dyferencjacyjnej układów zbiorowych i wykorzystywaniu możliwości, jakie niesie ze sobą prawo do zawierania układów zbiorowych pracy. Jednak niewielka liczba małych pracodawców, u których działają zakładowe organizacje związkowe, oraz słabość tych istniejących mają bez wątpienia wpływ na liczbę zawieranych układów zbiorowych i tym samym pracowników objętych ich postanowieniami. W doktrynie podnosi się również, że zbytnia koncentracja związków zawodowych na poziomie zakładowym w stosunku do ogólnej liczby związków, negatywnie wpływa na ilość układów zbiorowych, jak również osłabia znaczenia tych ostatnich jako stymulatora rozwoju prawa pracy ${ }^{9}$. Z punktu widzenia realizacji roli dyferencjacyjnej układów zbiorowych, pozytywnym zjawiskiem byłaby duża liczba układów zbiorowych zawieranych na poziomie ponadzakładowym. Tymczasem niewielka stopa uzwiązkowienia na poziomie ponadzakładowym, regulacje prawne oraz słaba pozycja struktur ponadzakładowych mają wpływ na praktykę układową na tym szczeblu.

Układy zbiorowe pełnią jednak nie tylko rolę dyferencjacyjną. $\mathrm{Z}$ punktu widzenia indywidualnego pracownika, układy zbiorowe powinny być przede wszystkim źródłem polepszenia jego warunków zatrudnienia w zakresie świadczeń ze stosunku pracy. Aby spełniały tę rolę, po pierwsze, u pracodawcy musi działać przynajmniej jedna organizacja związkowa, po drugie, partnerzy społeczni muszą być zainteresowani zawarciem układu zbiorowego, po trzecie, muszą mieć wolę wprowadzenia do układu postanowień będących źródłem podwyższenia świadczeń ze stosunku pracy, a nie tylko powielania rozwiązań ustawowych.

\footnotetext{
8 Por. J. Wratny, Wybrane problemy współczesnego prawa pracy w Polsce, Warszawa 1989, s. 58.

9 Por. J. Stelina, Refleksje na temat kondycji układów zbiorowych pracy w Polsce, [w:] Z zagadnień współczesnego prawa pracy. Księga Jubileuszowa Profesora Henryka Lewandowskiego, red. Z. GórAL, Warszawa 2009, s. 97 i n.
} 
Praktyka układowa pozwala na stwierdzenie, że spełnienie tych trzech warunków jest bardzo trudne.

Jak zostało to już wyżej zaznaczone, partnerzy społeczni nie mają zupełnej swobody w zakresie kształtowania postanowień układowych. Podstawą tego ograniczenia jest konstytucyjna zasada sprawiedliwości społecznej, jak również funkcja ochronna prawa pracy, której przejawem są zasada równego traktowania i niedyskryminacji w zatrudnieniu oraz zasada uprzywilejowania pracownika ${ }^{10}$. Celem tych ograniczeń jest zatem szeroko pojęta ochrona pracowników w zakresie warunków zatrudnienia. Ochronę tę mają zapewnić, z jednej strony, regulacje układowe będące przejawem sprawiedliwości społecznej i niedyskryminacji, a zatem podmiotami chronionymi w tym przypadku są pracownicy jako zbiorowość. W tym ujęciu ochrona będzie zatem polegać na standaryzowaniu warunków zatrudnienia w oparciu o kryteria zgodne z zasadą sprawiedliwości społecznej i równego traktowania w zatrudnieniu. $\mathrm{Z}$ drugiej jednak strony, ochrona ma zapewnić warunki zatrudnienia na poziomie nie niższym aniżeli gwarantują regulacje prawne, co jest konsekwencją zasady uprzywilejowania pracownika. Dopuszczalne jest jednak, a nawet wskazane, różnicowanie tych warunków w oparciu o ustalone w układzie zbiorowym pracy kryteria. W takim ujęciu ochrona skupia się nie tylko na pracownikach jako zbiorowości, ale ma gwarantować korelację między jakością pracy, a wysokością wynagrodzenia dla pracownika.

Charakter prawny układów zbiorowych pracy, jak również sposób ich zawierania oraz strony tychże układów zbiorowych są elementami, które powinny zapewniać obiektywizm kryteriów ustalania świadczeń ze stosunku pracy, w tym wynagrodzenia za pracę. Warunkiem niezbędnym jest sprecyzowanie kryteriów wysokości przyznawania tego świadczenia $w$ układzie zbiorowym pracy. W przeciwnym bowiem przypadku, kiedy kryteria układowe w tym zakresie będą powieleniem art. $78 \$ 1$ k. p., układ przestaje być źródłem ich obiektywizacji. W sytuacji

10 Por. L. GARlicki, Polskie prawo konstytucyjne zarys wykładu, Warszawa 1998, s. 62; M. SKĄPSKI, Ochronna funkcja prawa pracy w gospodarce rynkowej, Kraków 2006, s. 10 i n. 
takiej będziemy mieć również do czynienia z naruszeniem art. $78 \$ 2 \mathrm{k}$. p., który wyraźnie wskazuje na konieczność określenia w układzie zbiorowym pracy zasad przyznawania pracownikom stawek wynagrodzenia za pracę. Wedle tego przepisu stawki te powinny być uzależnione od rodzaju pracy lub stanowiska.

Należy zgodzić się z poglądami prezentowanymi w doktrynie, że wykładnia językowa art. $78 \$ 1$ k.p. wskazuje na hierarchizację wymienionych w nim mierników wartościowania pracy. Na czele tej hierarchii bez wątpienia umieszczone są rodzaj pracy i kwalifikacje wymagane do jej wykonywania, które należy traktować jako obligatoryjne mierniki wartościowania wynagrodzenia, w przeciwieństwie do ilości i jakości świadczonej pracy, które są miernikami uzupełniającymi w stosunku do wyżej wymienionych ${ }^{11}$. Wydaje się jednak, że w przypadku autonomicznych źródeł prawa kryteria uzupełniające powinny być ujęte i doprecyzowane przy wartościowaniu wynagrodzenia.

Kryterium różnicowania wynagrodzenia zależnie od rodzaju świadczonej pracy ma ścisły związek z kryterium kwalifikacji pracownika, bowiem nie chodzi o jakiekolwiek kwalifikacje, ale kwalifikacje do wykonywania pracy danego rodzaju. Istotną rolę $\mathrm{w}$ procesie obiektywizacji kryteriów wynagrodzenia, jeśli wziąć pod uwagę układy zbiorowe, pełnią taryfikatory klasyfikacyjne i tabele płac, będące wyrazem uwzględnienia kwalifikacji w procesie różnicowania wynagrodzeń. W związku z obligatoryjnym udziałem partnerów społecznych przy ich tworzeniu, są one wyrazem kompromisu między oczekiwaniami pracowników manifestującymi się w stanowisku związków zawodowych, a propozycjami pracodawcy. Aby ten kompromis mógł zostać osiągnięty, związki zawodowe muszą dysponować wiedzą co do możliwości finansowych pracodawcy. Stanowisko związków zawodowych co do wartościowania wynagrodzenia, a przede wszystkim treści tabeli płac, powinno zatem być wypadkową oczekiwań pracowników i realnych możliwości pracodawcy, w przeciwnym razie układ zbiorowy nie będzie pełnił istotnej roli w wartościowaniu wynagrodzenia albo nie

11 Por. B. Wagner, [w:] Kodeks pracy. Komentarz, red. T. Zieliński, Warszawa 2000, s. 435. 
zostanie zawarty, w związku z forsowaniem stanowiska przez jedną ze stron. Mimo szerokiego zakresu przedmiotowego układów zbiorowych pracy, kwestie związane $\mathrm{z}$ wynagrodzeniami są bez wątpienia jednymi z najistotniejszych, które powinny zdaniem pracowników zostać uregulowane w układzie zbiorowym.

Konieczność wartościowania pracy w oparciu o rodzaj pracy, czyli ocenę pracy i kwalifikacje pracownika, czyli tym samym ocenę pracownika, nie budzi wątpliwości ${ }^{12}$. Wydaje się, że jej istotnym z praktycznego punktu widzenia dopełnieniem będą mierniki wartościowania w postaci ilości i jakości świadczonej pracy. Zatem, aby kryteria ustalania wysokości wynagrodzenia można było uznać za obiektywne i zgodne z przepisami prawa, wysokość wynagrodzenia musi być uzależniona od obligatoryjnych mierników wartościowania wynagrodzenia, czyli rodzaju pracy i posiadanych kwalifikacji, przy uwzględnieniu mierników uzupełniających w postaci ilości i jakości świadczonej pracy oraz muszą zostać sprecyzowane zasady przyznawania pracownikom stawek za pracę określonego rodzaju lub na określonym stanowisku.

$\mathrm{Z}$ analizy zakładowych układów zbiorowych pracy wynika, że w źródłach tych niejednokrotnie powiela się ogólne kryteria ustalania wysokości wynagrodzenia, wynikające z kodeksu pracy, czyli odpowiadające rodzajowi świadczonej pracy, kwalifikacjom wymaganym przy jej wykonaniu z uwzględnieniem ilości i jakości świadczonej pracy ${ }^{13}$. W niektórych przypadkach układ zbiorowy pracy w postanowieniach określających ogólne kryteria ustalania wysokości wynagrodzenia,

12 Więcej na temat oceny pracy i oceny pracownika J. Wratny, Kodeks pracy. Komentarz, Warszawa 2004, s. 193.

13 Art. 5 ust. 4 Zakładowego Układu Zbiorowego Pracy dla Pracowników Poczty Polskiej S.A. z 2010 r. (wypowiedziany 15 lipca 2014r.) tekst dostępny na stronie internetowej http://www.kpzkrakow.republika.pl, dostęp 8 listopada 2015 r.; $\$ 26$ Zakładowego Układu Zbiorowego dla Pracowników Zatrudnionych przez Zakłady PKP CARGO S.A. z 2004 r.; \$10 Zakładowego Układu Zbiorowego Pracy dla pracowników zatrudnionych przez jednostki organizacyjne wchodzące w skład „PKP Intersity” S.A. z 2012; tekst dostępny na stronie internetowej http://zzkontra.com.pl, dostęp 8 listopada 2015 r.; $\$ 34$ Zakładowego układu zbiorowego pracy dla pracowników Arcelor Mittal Service Group Spółka z o.o. z maja 2010 r., tekst dostępny na stronie internetowej http://www. solidarnosc.mittal.net.pl, dostęp 8 listopada 2015 r. 
uzależnia wysokość i składniki tego wynagrodzenia od rodzaju i charakteru wykonywanej pracy ${ }^{14}$. Nie oznacza to jednak, że ilość i jakość świadczonej pracy będzie w takim przypadku bez znaczenia przy ustalaniu wysokości wynagrodzenia, skoro ten sam układ zbiorowy wprowadza postanowienie, zgodnie z którym wynagrodzenie przyznawane pracownikom zatrudnionym na stanowiskach robotniczych może mieć charakter godzinowy lub akordowy. W pierwszym przypadku stosuje się zasady, wedle których wysokość wynagrodzenie wynika z godzinowej stawki osobistego zaszeregowania określonego w umowie o pracę, zgodnie z tabelą stawek wynagrodzeń godzinowych wynikających z załącznika do układu zbiorowego. W drugim przypadku wynagrodzenie będzie uzależnione od efektów wykonywanej pracy ${ }^{15}$. Zatem mimo zakkcentowania rodzaju i charakteru wykonywanej pracy jako podstawowych kryteriów ustalania wysokości wynagrodzenia, układ uwzględnia również ilość i jakość świadczonej pracy, traktując je jako kryteria pomocnicze, ale jednocześnie różnicujące wysokość wynagrodzenia na konkretnych stanowiskach.

Omówiony wyżej przypadek nie jest jedynym, kiedy w układzie zbiorowym wprowadza się kryteria pomocnicze, czy dodatkowe, różnicujące wynagrodzenie na danym stanowisku. W jednym $\mathrm{z}$ układów zbiorowych obok odesłania do kodeksowych kryteriów ustalania wysokości wynagrodzenia wprowadza się postanowienie, zgodnie z którym wysokość wynagrodzenia powinna uwzględniać także wysiłek fizyczny i umysłowy towarzyszący wykonywaniu danej pracy, wpływ tej pracy na wyniki ekonomiczne, stopień uciążliwości i warunki, w jakich praca jest wykonywana oraz ocenę pracy pracownika i osiągniętych przez niego wyników ${ }^{16}$. W tym przypadku zatem kryteria uzupełniające mieszczą się w pojęciu jakości wykonywanej pracy, z wyjątkiem stopnia uciążliwości i warunków, w jakich ta praca jest wykonywana, kryterium to można

14 Por. $\$ 48$ Zakładowego układu zbiorowego pracy w Skanska S.A. z 2011 r. tekst dostępny na stronie internetowej http://zzp-skanska.pl /skanska/ zuzp, dostęp 8 listopada $2015 \mathrm{r}$.

15 Ibidem.

$16 \$ 34$ ust. 2 Zakładowego układu zbiorowego pracy dla pracowników Arcelor Mittal... 
jednak utożsamiać z jakością skoro ma na tę jakość istotny wpływ. Stopień uciążliwości pracy może w szczególności wpływać negatywnie na jej wydajność, ale również jakość, czynnik ten powinien więc być brany pod uwagę przy ocenie pracy pod kątem wysokości wynagrodzenia. Stopień uciążliwości będzie zatem elementem różnicującym wysokość wynagrodzenia, ale mającym ścisły związek z rodzajem wykonywanej pracy, nie będzie jednak przesłanką różnicującą wysokość wynagrodzenia w ramach tego samego rodzaju pracy i stanowiska.

Układ zbiorowy pracy niekiedy daje możliwość przekroczenia maksymalnej stawki wynagrodzenia godzinowego lub miesięcznego. Przesłanką uzasadniającą odstępstwa od stawek określonych w układzie zbiorowym pracy mogą być „szczególnie wysokie kwalifikacje pracownika”. Podstawą do przyznania indywidualnej stawki wynagrodzenia będzie umotywowany wniosek przełożonego pracownika ${ }^{17}$. Kolejnym przykładem indywidualnego spojrzenia na wysokość wynagrodzenia pracownika, mimo istniejących w układzie zbiorowym regulacji w zakresie stawek wynagrodzenia, jest regulacja, zgodnie $\mathrm{z}$ którą pracodawca może zaszeregować pracowników wyżej od ustalonego w taryfikatorze przedziału zaszeregowania. Dokonuje tego ad personam, informując o podjętych decyzjach zakładowe organizacje związkowe raz na kwartał, w ujęciu ilościowym i stanowisk, których dotyczą te odstępstwa ${ }^{18}$. Decyzja o przeszeregowaniu lub awansowaniu pracownika może być uzależniona również od oceny bezpośredniego przełożonego, przy czym powinno to nastąpić $\mathrm{z}$ poszanowaniem zasady równego traktowania i z uwzględnieniem kwalifikacji zawodowych pracownika, jego praktyki i doświadczenia zawodowego ${ }^{19}$. Zatem w przypadku formułowania kryteriów ustalania wysokości wynagrodzenia w układach zbiorowych pracy dominuje odesłanie do kryteriów kodeksowych, od których uzależniona jest również kwalifikacja pracownika i zaszeregowanie oraz w konsekwencji ostateczna wysokość wynagrodzenia zasadniczego. Układy zbiorowe wprowadzają jednak również własne

\footnotetext{
$17 \$ 48$ ust. 3.1 Zakładowego układu zbiorowego pracy w Skanska S.A....

$18 \$ 36$ Zakładowego układu zbiorowego pracy dla pracowników Arcelor Mittal...,

19 Art. 12 ust. 2 Zakładowego Układu Zbiorowego Pracy dla Pracowników Poczty Polskiej S.A....
} 
rozwiązania w zakresie kryteriów wynagrodzenia, mające charakter bardziej zindywidualizowany aniżeli kryteria kodeksowe. Rozwiązania te dają pracodawcy większą swobodę w zakresie ustalania wysokości wynagrodzenia, aniżeli tylko przyznawanie go w ramach określonych w tabelach zaszeregowania widełek. $Z$ drugiej jednak strony pojawia się pytanie, czy nie zmniejszają obiektywizmu kryteriów określania wysokości wynagrodzenia. Odpowiedź na tak postawione pytanie wydaje się być negatywna, skoro indywidualne podejście do wynagrodzenia pracownika jest uzależnione od spełnienia określonych przesłanek, tak jak była o tym mowa wyżej. Ponadto niekiedy układ zbiorowy wprowadza wymóg informowania zakładowych organizacji związkowych o podjętych decyzjach dotyczących np. wyższego zaszeregowania danego pracownika,. Organizacje te nie mają co prawda wpływu na decyzje pracodawcy w tym zakresie, ale już sam fakt wymogu informowania związków zawodowych stanowi niejako przejaw „prewencji” w dowolności podejmowanych decyzji.

Istotną rolę w procesie obiektywizacji kryteriów ustalania wysokości wynagrodzenia pełnią tabele stanowisk, zaszeregowań oraz wymagań kwalifikacyjnych, będące podstawą zaszeregowania pracownika do odpowiedniej kategorii wynagrodzenia zasadniczego. Przesłanką uzasadniającą zaszeregowanie pracownika do odpowiedniej kategorii jest stanowisko, natomiast najczęstszą podstawą do zatrudnienia na dany stanowisku, jak wynika $\mathrm{z}$ analizy załączników do układów zbiorowych, są kwalifikacje i staż pracy. W przypadku oceny kwalifikacji bierze się pod uwagę rodzaj wykształcenia, jak również jego poziom czy też legitymowanie się egzaminami wymaganymi na danym stanowisku ${ }^{20}$. Należy jednak zwrócić uwagę na fakt, że obok obiektywnych kryteriów potwierdzających kwalifikacje pracownika niekiedy w układach zbiorowych pracy wprowadza się również takie, których obiektywizm trudno zweryfikować. Można do nich zaliczyć na przykład wykazanie przez pracownika uzdolnień kwalifikujących go do zatrudnienia na

20 Por. $\$ 11$ ust. 2 pkt. 2 Zakładowego Układu Zbiorowego Pracy dla pracowników zatrudnionych przez jednostki organizacyjne wchodzące w skład „PKP Intercity” S.A.... 
danym stanowisku ${ }^{21}$. Zważywszy jednak na fakt, że kryterium to występuje obok innych mających charakter obiektywny, może zostać ono potraktowane jako pomocnicze i uzupełniające względem pozostałych.

Podobnie obowiązek wykazania przygotowania do zajmowanego stanowiska wydaje się mieć mało obiektywny charakter. Skoro bowiem kryterium to występuje łącznie z kwalifikacjami wymaganymi do zajmowania danego stanowiska, nie należy go traktować jako tożsame z tymi kwalifikacjami. Stronom układu zbiorowego chodziło zatem o inne, aniżeli potwierdzenie kwalifikacji, informacje świadczące o przygotowaniu pracownika do wykonywania danej pracy. Można by było przyjąć, że potwierdzeniem tego przygotowania jest legitymowanie się pracownika odpowiednim stażem pracy potwierdzającym przygotowanie praktyczne, wówczas omawiane kryterium przybiera charakter obiektywny.

Istotne znaczenie $\mathrm{w}$ procesie zaszeregowania pracownika odgrywa staż pracy, zarówno ogólny, jak i staż pracy na danym stanowisku czy $\mathrm{w}$ danej specjalności. Układy zbiorowe pracy uzależniają od stażu w danej specjalności wyższy stopień zaszeregowania pracownika mimo niższych kwalifikacji. Jednocześnie jednak niekiedy dopuszczają zwolnienie pracownika od wymogu stażu pracy w przypadku, gdy posiada on wysokie kwalifikacje zawodowe i pełną przydatność do wykonywania pracy na danym stanowisku ${ }^{22}$. To ostatnie kryterium wydaje się mieć charakter czysto ocenny, bowiem pełną przydatność do wykonywania pracy należałoby traktować jako klauzulę generalną. Z racji braku wskazówek precyzujących w układzie zbiorowym można przyjąć, że wymiar tej przydatności ocenia pracodawca.

Reasumując, układowe kryteria ustalania wysokości wynagrodzenia pełnią rolę pomocniczą i konkretyzującą względem kryteriów wynikających z kodeksu pracy. W postanowieniach układowych nie brak jednak również kryteriów mało konkretnych, sformułowanych ogólnie, które przybierają charakter ocenny i gwarantują większą elastyczność

21 Por. Art. 9 ust. 2 Zakładowego Układu Zbiorowego Pracy dla Pracowników Poczty Polskiej S.A....

22 Por. załącznik nr 1 do Zakładowego Układu zbiorowego dla pracowników, PKP Polskie Linie Kolejowe Spółka Akcyjna”... 
w zakresie kształtowania wysokości wynagrodzenia indywidualnego pracownika.

3. OgÓLNE SFORMUŁOWANIE KRYTERIÓW USTALANIA WYSOKOŚCI WYNAGRODZENIA W KODEKSIE PRACY I UKŁADACH ZBIOROWYCH JAKO CZYNNIK WARUNKUJĄCY SWOBODĘ KSZTAETOWANIA WYSOKOŚCI TEGO ŚWIADCZENIA PRZEZ STRONY UMOWY O PRACE

Jeżeli u pracodawcy został zawarty układ zbiorowy pracy, to na etapie tworzenia stosunku pracy, strony umowy określając wysokość wynagrodzenia, są związane postanowieniami układu zbiorowego, które mimo wszystko pozostawiają im pewne pole manewru w ramach wprowadzonych widełek czy też kryteriów niedookreślonych. Swobody tej nie należy rozpatrywać w kategoriach negatywnych. Pracodawca, zatrudniając pracownika, powinien mieć bowiem możliwość proponowania mu warunków wynagrodzenia stosownie do atutów, którymi dysponuje kandydat na pracownika. Dominującą rolę wśród nich powinny pełnić te o charakterze obiektywnym, jak kwalifikacje, staż pracy. Należy jednak pamiętać, że nie są one jedynym wyznacznikiem przydatności pracownika do wykonywania pracy na danym stanowisku. Wyznacznikiem takim mogą być również predyspozycje do wykonywania pracy danego rodzaju, które będą podlegały ocenie pracodawcy, niekoniecznie jednak będą weryfikowalne.

Jeżeli natomiast pracownicy nie są objęci postanowieniami autonomicznych źródeł praw pracy, ogólnie sformułowane kryteria kodeksowe gwarantują swobodę kształtowania wysokości wynagrodzenia za pracę, mając na względzie oczywiście ograniczenia wynikające $z$ innych niż kodeks pracy powszechnych źródeł prawa. Pojawia się w związku z tym pytanie, czy i w jakim zakresie swoboda w kształtowaniu wysokości wynagrodzenia jest przejawem wpływu cywilistycznej zasady swobody umów na kształtowanie wysokości tego świadczenia?

Odpowiedź na to pytanie będzie twierdząca, pod warunkiem że swobodę wynikającą z tej zasady ograniczymy regulacjami prawnymi 
będącymi przejawem funkcji ochronnej prawa pracy. Przejawem tego ograniczenia są nie tylko postanowienia autonomicznych źródeł prawa pracy, ale również przepisów powszechnie obowiązujących, na przykład ustawa o minimalnym wynagrodzeniu za pracę. Skoro zasadniczym celem funkcji ochronnej prawa pracy jest zrównoważenia dysproporcji, jaka w sensie faktycznym występuje między stronami stosunku pracy, funkcja ta $\mathrm{z}$ definicji stanowi ograniczenie cywilistycznej zasady swobody tworzenia umów. Ograniczenie nie oznacza jednak jej całkowitej eliminacji ze stosunków pracy. Nie można bowiem stron stosunku pracy pozbawić zupełnie możliwości kształtowania warunków zatrudnienia. Ogólne sformułowanie kryteriów ustalania wysokości wynagrodzenia daje możliwość negocjacji, a zarówno postanowienia autonomicznych źródeł prawa pracy, jak i przepisy powszechnych źródeł prawa wyznaczają ramy tych negocjacji w zakresie wysokości wynagrodzenia.

Ostateczna wysokość wynagrodzenia proponowanego przez pracodawcę jest więc wypadkową kilku czynników: tych zależnych od pracodawcy, ale również tych zależnych od pracownika. Do pierwszej grupy zaliczamy rodzaj pracy, możliwości finansowe i standardy pracodawcy w zakresie wynagradzania pracowników, do drugiej zaś kwalifikacje pracownika, w którym to pojęciu będzie się mieścić zarówno wykształcenie, jak i staż pracy na danym stanowisku czy też przy pracy danego rodzaju. Czynnikiem zależnym od pracownika, który może mieć wpływ na wysokość wynagrodzenia, jest również pozycja negocjacyjna pracownika na rynku pracy.

Pozycja negocjacyjna pracownika to z kolei wypadkowa wielu czynników mających bezpośredni związek zarówno z osobą pracownika, jak i związanych z pracodawcą oraz czynników o charakterze zewnętrznym. Do tych pierwszych należy zaliczyć umiejętności pracownika oraz jego predyspozycje umożliwiające nabycie mu tych umiejętności. Czynniki związane z pracodawcą, mające wpływ na pozycję negocjacyjną pracownika, to $z$ kolei regulacje określające kryteria ustalania wysokości świadczeń ze stosunku pracy, wynikające z autonomicznych źródeł prawa pracy. Kandydat na pracownika nie jest objęty co prawda postanowieniami układu zbiorowego, nie obejmują go również bezpośrednio regulacje wynikające $\mathrm{z}$ regulaminu wynagradzania. $\mathrm{W}$ momencie 
zawarcia umowy o pracę będą jednak źródłem ustalania jego świadczeń ze stosunku pracy, poza tym wyznaczają standardy w zakresie wysokości tych świadczeń, jakie obowiązują u danego pracodawcy. Te dwie grupy czynników mogą wzmacniać albo osłabiać pozycję negocjacyjną pracownika. Tymczasem czynniki zewnętrzne współcześnie głównie osłabiają skuteczność negocjacyjną pracownika. Zaliczyć do nich można stopę bezrobocia czy nasycenie rynku pracy przedstawicielami danego zawodu.

4. WSPÓŁCZESNY RYNEK PRACY I JEGO WPŁYW NA ROLĘ UKŁADÓW ZBIOROWYCH PRACY. UWAGI PODSUMOWUJĄCE

Rynek pracy nie ma bezpośredniego wpływu na rolę autonomicznych źródeł prawa pracy, ma jednak wpływ pośredni. Można bowiem bez wątpienia doszukać się związku między sytuacją na rynku pracy a stopą uzwiązkowienia. Brak stabilności zatrudnienia i szybka rotacja pracowników nie sprzyja tworzeniu zakładowych organizacji związkowych. Stopa uzwiązkowienia ma natomiast wpływ bezpośredni na rolę autonomicznych źródeł prawa pracy. Skoro bowiem brak jest partnerów społecznych, wykluczona jest możliwość zawierania układów zbiorowych pracy. Spadek liczby układów zmniejsza ich rolę w ujęciu ogólnym prawa pracy, skoro zmniejsza się liczba pracowników objętych postanowieniami układowymi.

Roli układów zbiorowych nie można jednak oceniać wyłącznie przez pryzmat negatywnych zjawisk na rynku pracy. Te negatywne zjawiska nie mogą bowiem deprecjonować układów zbiorowych. Do ewidentnych zalet kształtowania kryteriów ustalania świadczeń ze stosunku pracy w drodze układowej należy zaliczyć udział partnerów społecznych $\mathrm{w}$ ich tworzeniu, gwarantujący większy obiektywizm kryteriów w nich zawartych. Poprzez obiektywizm kryteriów ustalenia wysokości świadczeń zmniejszają one ryzyko naruszenia zasady zakazu dyskryminacji. Związki zawodowe reprezentujące pracowników w rokowaniach układowych mają bez wątpienia silniejszą pozycję negocjacyjną aniżeli indywidualny pracownik, co może mieć wpływ na wynegocjowanie 
korzystniejszych warunków wynagrodzenia. Obowiązujący u danego pracodawcy układ zbiorowy pracy może z kolei wzmocnić pozycję negocjacyjną przyszłego pracownika co do warunków jego wynagrodzenia. Ponadto układ zbiorowy pracy pełni rolę źródła informacji dla potencjalnych pracowników co do standardów finansowych obowiązujących u danego pracodawcy. Może wpływać motywująco na pracowników, jeżeli pracodawca stosuje jasne kryteria awansu zawodowego, co powinno mieć przełożenie na wysokość wynagrodzenia. Układ zbiorowy pracy jest wypadkową oczekiwań pracowników co do wysokości wynagrodzenia i możliwości pracodawcy w tym zakresie. Wpływa zatem pozytywnie na wzajemne relacje między stronami stosunku pracy.

Dużo trudniejsza natomiast jest odpowiedź na pytanie o przyszłość układów zbiorowych pracy, skoro możemy jedynie spekulować co do przyczyn niewielkiej ilości zawieranych układów. Wydaje się jednak, że z uwagi na ewidentne zalety tego typu źródeł prawa pracy w sprzyjających okolicznościach zwiększy się liczba zawieranych układów zbiorowych. Chodzi tu zarówno o okoliczności pozaprawne, jak i prawne. Do tych pierwszych możemy bez wątpienia zaliczyć wzrost świadomości prawnej wśród samych pracowników co do znaczenia autonomicznych źródeł praw pracy w procesie kształtowania warunków zatrudnienia. Będzie to być może czynnik sprzyjający wzrostowi stopy uzwiązkowienia. Skuteczność mechanizmów prawnych związanych z reprezentacją pracowników zależy bowiem od świadomości prawnej samych pracowników, której konsekwencją może być przekonanie o skuteczności przedstawicielstw pracowniczych. Same regulacje prawne, nawet najdoskonalsze, nie sprawdzą się w praktyce, jeżeli pracowniczy nie będą przekonani o pozytywnych skutkach ich stosowania ${ }^{23}$. Nie oznacza to jednak, że zmiana regulacji prawnych dotyczących działu XI k. p. nie będzie pomocna w zakresie poprawy praktyki układowej. Zważywszy na fakt, że u bardzo wielu pracodawców nie działają zakładowe organizacje związkowe, co ma bezpośredni wpływ na liczbę zawieranych układów zbiorowych, alternatywą mogą być układy ponadzakładowe. Konieczne

23 A. Kowalczyк, Pojęcie i skutki prawne zasady reprezentatywności związków zawodowych w prawie polskim, Rzeszów 2014, s. 179. 
wydają się zmiany regulacji prawnych dotyczących stron układów ponadzakładowych. Obecnie obowiązujące regulacje prawne utrudniają rozwój praktyki układowej. Należałoby może skorzystać z propozycji zawartych w projekcie zbiorowego kodeksu pracy i kompetencje w zakresie zawierania układów zbiorowych powierzyć organizacji związkowej reprezentującej pracowników i organizacji pracodawców reprezentującej jej członków. W przypadku sfery budżetowej pracodawcę reprezentowałby minister lub inny organ, albo wójt, burmistrz, prezydent, starosta, marszałek województwa, przewodniczący zarządu związku samorządowego. Aczkolwiek w przypadku samorządowej sfery budżetowej należałoby się zastanowić nad zmianą koncepcji pracodawcy, polegającą na wprowadzeniu modelu właścicielskiego, co gwarantowałoby przejrzystość regulacji prawnych i odpowiedzialności za zobowiązania finansowe wynikające $\mathrm{z}$ układu zbiorowego. Konieczna bez wątpienia jest zamiana regulacji prawnych $\mathrm{w}$ zakresie kryteriów reprezentatywności zarówno na szczeblu ponadzakładowym, jak i zakładowym. Pod rozwagę należy również wziąć zmianę przepisów w zakresie ograniczeń podmiotowych, polegającą na wprowadzeniu zakazu zawierania układów zbiorowych dla sędziów i prokuratorów, ewentualnie pracowników administracji państwowej zatrudnionych na podstawie mianowania. Zmiany wymagają również regulacje prawne dotyczące reprezentatywności związków zawodowych, zarówno w zakresie kryteriów, jak i trybu stwierdzania reprezentatywności. Najpełniejsze wykorzystanie zasady reprezentatywności jest możliwe w przypadku wysokiej stopy uzwiązkowienia. Spadek tej stopy pociąga za sobą konieczność dostosowania regulacji do realiów. Konieczna wydaje się być przynajmniej liberalizacja proponowanych przez ustawodawcę kryteriów na szczeblu ponadzakładowym. Warto by rozważyć możliwość zastąpienia wprowadzonych przez ustawodawcę kryteriów liczbowych kryterium najliczniejszego związku zawodowego. Na szczeblu zakładowym lepszym rozwiązaniem od kryteriów ilościowych wydaje się być referendum ${ }^{24}$. Zmiany w tym zakresie mogą również pozytywnie wpłynąć na liczbę zawieranych układów zbiorowych.

24 Ibidem, s. 172, 173. 
Objective Criteria for the Determination of Pay, and Collective Labour Agreements

\section{Summary}

Important aspects of the process of determining pay, from the viewpoint of employees, include not only the pay rate, but also the objectivity of criteria taken into account to calculate it. This is because objective criteria are needed to make an employee's pay right in consideration of both his job and qualifications. Collective labour agreements play an important role in the process of establishing objective criteria for employees' pay. While the Polish Labour Code describes the criteria in general terms, collective labour agreements should stipulate them in a more specific manner. On the basis of a review of selected collective agreement systems, the author shows to what extent, from the point of view of these collective agreement systems, the solutions applied provide grounds for the objectivity of criteria applied for the calculation of pay. The article also discusses the criteria which employers should apply to calculate their employees' pay, since the criteria now in use are not objective enough and employers find them hard to verify.

Słowa kluczowe: ekwiwalent, pracownik, pracodawca, związek zawodowy

Keywords: equivalent, employee, employers, trade union.

\section{Bibliografia:}

Florek LudwiK, Ustawa i umowa w prawie pracy, Warszawa 2010

GARLICKI LeszeK, Polskie prawo konstytucyjne zarys wykładu, Warszawa 1998 GoźDziewicz Grzegorz, Podstawowe zasady zbiorowego prawa pracy [w:] Zbiorowe prawo pracy w społecznej gospodarce rynkowej, red. GRZEGORZ GoźDziewicz, Toruń 2000

Kowalczy k Aneta, Pojęcie i skutki prawne zasady reprezentatywności związków zawodowych w prawie polskim, Rzeszów 2014

KowalCzy A Aneta, Rola związków zawodowych w negocjacjach w sprawach pracowniczych [w:] Prawo pracy czynnikiem skutecznego kierowania ludźmi, red. ANDRZEJ NowAK, Radom 2013 
MASEWICZ WALERY, Ustawa o zwiazkach zawodowych. Ustawa o rozwiąywaniu sporów zbiorowych, Warszawa 1998

SAlwa ZBigniew, Uprawnienia związków zawodowych, Bydgoszcz 1998

SKĄPSKI MichaE, Ochronna funkcja prawa pracy w gospodarce rynkowej, Kraków 2006

Stelina JaKub, Refleksje na temat kondycji układów zbiorowych pracy w Polsce, [w:] Z zagadnień wspótczesnego prawa pracy. Księga Jubileuszowa Profesora Henryka Lewandowskiego, red. ZBIGNIEw GóRAL, Warszawa 2009

SzewCZy K HeLena, Układ zbiorowy pracy jako źródło dyferencjacji warunków zatrudnienia, «Monitor Prawa Pracy» 5/2014

SZUBert WACŁAW, Rola układów zbiorowych $w$ dalszym rozwoju prawa pracy, Łódź 1974

Wagner Barbara, [w:] Kodeks pracy. Komentarz, red. Tadeusz Zieliński, Warszawa 2000

Wratny Jerzy, Kodeks pracy. Komentarz, Warszawa 2004

Wratny Jerzy, Państwo jako regulator stosunków pracy - tendencje zmian, «PiZS» 10/2004

Wratny Jerzy, Problem funkcji promocyjnej układów zbiorowych pracy $w$ świetle zmian prawa pracy, [w:] Nowe układy zbiorowe. Przełom czy kontynuacja?, red. JERZY WratnY, Warszawa 1997

Wratny JeRzy, Wybrane problemy wspólczesnego prawa pracy w Polsce, Warszawa 1989

Wratny Jerzy, Źródła prawa pracy w ujęciu prawnoporównawczym, [w:] Źródła i instytucje prawa pracy w ujęciu porównawczym, red. JERZY WRATNY, Warszawa 1987

Zieliński Tadeusz, Kodeks pracy. Komentarz, Warszawa 2000

Zieliński Tadeusz, Prawo pracy. Zarys systemu. Cz. I Ogólna, Warszawa-Kraków 1986

Wykaz stron internetowych:

http://www.kpzkrakow.republika.pl, dostęp 8 listopada 2015 r.

http://www.solidarnosc.mittal.net.pl, dostęp 8 listopada 2015 r.

http://zzkontra.com.pl, dostęp 8 listopada 2015 r.

http://zzp-skanska.pl/skanska/zuzp, dostęp 8 listopada 2015 r. 